\title{
PENYIMPANGAN IMPLIKATUR PERCAKAPAN DALAM HUMOR-HUMOR GUS DUR
}

\author{
Dwi Budiyanto \\ FBS Universitas Negeri Yogyakarta \\ e-mail: matahati01@yahoo.com
}

\begin{abstract}
This study aims to describe forms of speech implicature violations in the discourse of Gus Dur's humors. The data sources were collections of his humors in okezone.com and gusdur.net. The data were analyzed using the descriptive technique involving tabulation, categorization, and inference. The data were selected and categorized on the basis of the maxim violations and then analyzed and inferred in accordance with types and forms of violations from the cooperative and politeness principles. The results show that humorous effects in Gus Dur's humors are made through the utilization of speech implicature violations. In the cooperative principle, there are violations from the maxims of quantity, quality, relevance, and manner. In the politeness principle, there are violations from maxims of generosity, approbation, and modesty.
\end{abstract}

Keywords : discourse of humor, speech implicature, cooperative principle, politeness principle

\section{PENDAHULUAN}

Humor telah menjadi bagian dari kehidupan masyarakat Indonesia. Sebagai fenomena kebahasaan humor dapat ditemukan di banyak tempat dan tradisi. Kehadiran humor dalam masyarakat merupakan fenomena menarik. Humor tidak hanya diterima masyarakat, tetapi sekaligus menjadi bagian yang tidak terpisahkan dari masyarakat. Masyarakat menyampaikan sesuatu yang dirasakan dalam hatinya secara tidak langsung melalui humor, lelucon, atau anekdot. Keinginan, keisengan, kejengkelan, kemarahan, dan semacamnya dapat diungkapkan melalui lelucon atau anekdot (Danandjaja, 1999).

Humor dapat ditemukan hampir di semua lapisan masyarakat. Doyin (2006) menjelaskan bahwa berdasarkan penelitiannya humor dapat diklasifikasikan berdasarkan segmentasinya. Ada humor untuk kalangan mahasiswa, pesantren, pasangan suami istri, peja- bat, dan sebagainya.

Humor dilakukan oleh seseorang atau kelompok orang untuk melampiaskan perasaan tertekan dan mengurangi berbagai ketegangan dalam kehidupan sehari-hari. Kegiatan berhumor antara penutur dan lawan tutur termasuk dalam tindak tutur. Pada kenyataannya, tindak tutur dalam wacana humor ada yang disampaikan secara jelas dan langsung sehingga dapat ditangkap maksudnya. Namun, ada juga yang disampaikan secara terselubung.

Wacana humor yang penyampaian maksudnya dilakukan secara terselubung merupakan bagian dari implikatur percakapan (conversation implicature). Dalam wacana humor, penggunaan implikatur percakapan akan menimbulkan kelucuan, kegelian atau tertawa bagi lawan tutur yang dapat menangkap maksud yang disampaikan dalam wacana humor tersebut. Apabila lawan tutur tidak dapat menangkap 
maksud wacana humor yang mengandung implikatur percakapan sudah dapat dipastikan orang tersebut tidak akan merasa lucu, geli, atau tertawa, bahkan dia bisa marah dalam menanggapi wacana yang dimaksudkan sebagai humor itu.

Grice (1975) ketika membahas implikatur percakapan menegaskan bahwa dalam tindak tutur diperlukan seperangkat asumsi yang akan menjadikan proses komunikasi menjadi lebih efektif dan efisien. Antara penutur dan lawan tutur harus bersifat kooperatif. Oleh karena itu, penutur dan lawan tutur harus mematuhi prinsip kerjasama (cooperative principles) dan prinsip kesopanan. Dengan berpedoman pada prinsip kerjasama dan kesopanan maka proses komunikasi akan berlangsung lancar dan jelas. Hanya saja tidak selamanya dalam praktik komunikasi dua prinsip tersebut dipatuhi. Dalam wacana humor, misalnya, secara sengaja kedua prinsip tersebut disimpangkan.

Tujuan utama penyimpangan dalam aspek pragmatik wacana humor adalah untuk menimbulkan efek kelucuan. Hal ini terlihat dalam humor-humor Gus Dur atau KH Abdurrahman Wahid. Gus Dur memanfaatkan penyimpangan prinsip kerjasama dan kesopanan untuk memunculkan rasa lucu. Humor-humor Gus Dur menunjukkan pemakaian kebahasaan yang khas karena mampu menimbulkan kelucuan. Gus Dur melalui humor-humornya diakui telah menciptakan tradisi baru yang lebih santai, nonformal, akrab, dan tidak terikat oleh protokoler yang kaku dan mengikat. Penelitian ini berusaha menjelaskan penyimpangan-penyimpangan yang terjadi dalam humor-humor Gus Dur, terutama dalam aspek pragmatik. Penyimpangan implikatur percakapan yang dimaksud terkait dengan penyimpangan prinsip kerjasama (cooperative principles) dan prinsip kesopanan (polite- ness principles).

Humor memiliki peranan yang sentral dalam kehidupan manusia, yaitu sebagai sarana hiburan dan pendidikan untuk meningkatkan kualitas hidup manusia. Dalam situasi hidup yang memburuk, humor dapat dijadikan pelipur lara dan hiburan yang menyenangkan. Sementara itu dalam situasi masyarakat yang terdegradasi humor dapat dijadikan sarana kritik sosial yang tajam, tetapi mampu menimbulkan efek kelucuan. Masyarakat penikmat humor akan mengalami dua hal sekaligus, yaitu terhibur dan tercerahkan.

Penjelasan di atas menegaskan bahwa humor merupakan rangsangan yang mempunyai potensi untuk memancing tawa. Namun demikian, menurut Rustono (1988, dalam Mulyani, 2002) humor tidaklah sekedar berupa kemampuan menghibur dan menggelikan melalui ujaran atau tulisan. Satuan kebahasaan yang dapat berperan sebagai rangsangan munculnya tawa harus dikreasi dengan kriteria-kriteria tertentu.

Wijana (2003) menjelaskan bahwa dari sudut pandang linguistik humor dikembangkan dari konsep ketidaksejajaran (incongruity) dan pertentangan (conflict). Ketidaksejajaran dan pertentangan itu terjadi karena dilanggarnya norma-norma pragmatik bahasa, baik secara tekstual maupun interpersonal. Secara tekstual, pelanggaran dilakukan dengan penyimpangan prinsip kerjasama. Sementara itu, secara interpersonal dilakukan dengan pelanggaran prinsip kesopanan dan parameter pragmatik.

Pelanggaran aspek pragmatik tersebut dapat menimbulkan efek kelucuan karena bagian-bagian dari kreasi kebahasaan yang disimpangkan tersebut dipersepsi secara tiba-tiba oleh penikmat humor. Humor-humor yang disampaikan Gus Dur kebanyakan direspon dan menimbulkan efek kelucuan bagi penikmatnya, terlebih ketika humor- 
humor tersebut secara mudah mulai banyak diakses oleh masyarakat. Secara linguistik Gus Dur memanfaatkan kreasi kebahasaan di atas untuk menghadirkan efek lucu dalam humor-humornya.

Efek kelucuan dalam humor ditimbulkan melalui pemanfaatan kreasi bahasa tertentu. Berdasarkan pendekatan pragmatik, pada hakikatnya humor terjadi karena penyimpangan dua jenis implikatur, yakni implikatur konvensional (conventional implicature) dan implikatur percakapan (conversational implicature) (Wijana, 2003). Jenis implikatur pertama terkait dengan makna bentuk-bentuk linguistik, sedangkan yang kedua menyangkut elemen-elemen wacana yang harus mematuhi prinsipprinsip pertuturan.

Wacana humor berusaha menyimpangkan prinsip pertuturan yang seharusnya dipatuhi dalam proses komunikasi. Dalam proses komunikasi, penutur dan lawan tutur seharusnya mematuhi prinsip kerjasama (cooperative principles) dan prinsip kesopanan sebagai bagian dari prinsip pertuturan. Dengan berpedoman pada prinsip kerjasama dan kesopanan maka proses komunikasi akan berlangsung lancar dan jelas. Hanya saja tidak selamanya dalam praktik komunikasi dua prinsip tersebut dipatuhi. Dalam wacana humor, misalnya, secara sengaja kedua prinsip tersebut disimpangkan.

Prinsip kerjasama menurut Grice (1975) dijabarkan dalam beberapa maksim, yaitu (1) maksim kuantitas (maxim of quantity), (2) maksim kualitas (maxim of quolity), (3) maksim relevansi (maxim of relevance), dan (4) maksim cara (maxim of manner). Selain itu, menurut Leech (1983) dalam proses komunikasi perlu ditambahkan prinsip kesopanan (politeness principles). Prinsip kesopanan memiliki beberapa maksim, yaitu (1) maksim kebijaksanaan (tact maxim), (2) maksim kemurahan (generosity maxim),
(3) maksim penerimaan (approbation maxim), (4) maksim kerendahhatian (modesty maxim), (5) maksim kecocokan (agreement maxim), dan (6) maksim kesimpatian (sympathy maxim) (Wijana, 2003; Mulyani, 2002).

Terkait dengan maksim-maksim dalam prinsip kerjasama dapat dijelaskan sebagai berikut. Maksim kuantitas menghendaki setiap peserta tutur memberikan kontribusi yang secukupnya atau sebanyak yang dibutuhkan oleh lawan tuturnya. Maksim kualitas mengharuskan setiap peserta tutur untuk mengatakan sesuatu yang sebenarnya. Maksim relevansi mewajibkan peserta tutur untuk memberikan kontribusi yang relevan dengan masalah pembicaraan, sedangkan maksim pelaksanaan menghendaki peserta tutur berbicara secara langsung, tidak kabur, dan tidak berlebihan, serta runtut.

Sementara itu, terkait dengan maksim-maksim dalam prinsip kesopanan dapat dipaparkan sebagai berikut. Maksim kebijaksanaan menghendaki peserta tutur meminimalkan kerugian orang lain atau memaksimalkan keuntungan orang lain. Maksim kemurahan menuntut peserta tutur memaksimalkan penghormatan kepada orang lain. Maksim penerimaan mewajibkan peserta tutur memaksimalkan kerugian bagi diri sendiri atau meminimalkan keuntungan bagi diri sendiri. Maksim kerendahhatiaan mengharuskan peserta tutur memaksimalkan ketidakhormatan pada diri sendiri atau meminimalkan penghormatan pada diri sendiri. Maksim kecocokan menghendaki peserta tutur untuk memaksimalkan kecocokan di antaranya atau meminimalkan rasa ketidakcocokan. Sementara itu, maksim kesimpatian mengharuskan setiap peserta tutur memaksimalkan rasa simpati atau meminimalkan rasa antipati kepada lawan tuturnya (Wijana, 2003). 


\section{METODE}

Penelitian ini berusaha mendeskripsikan penyimpangan aspek pragmatik dalam wacana humor Gus Dur yang berfungsi untuk menimbulkan efek kelucuan. Sumber data adalah wacana humor Gus Dur yang diakses dari internet, terutama dari okezone.zom dan gusdur.net. Data tersebut dikumpulkan dengan menggunakan teknik catat. Data dicatat dengan menggunakan kartu data. Ada dua bagian dalam kartu data, yaitu bagian deskripsi dan bagian refleksi. Bagian deskripsi digunakan untuk memuat penggalan wacana humor yang menyimpang dari implikatur percakapan, terutama dari prinsip kerjasama dan prinsip kesopanan. Sementara itu, bagian refleksi berisi hasil interpretasi terhadap jenis penyimpangan terhadap maksim-maksim dari implikatur percakapan di atas.

Validitas data dicapai melalui validitas semantik dalam hal ini dalam hal ini pemaknaan satuan lingual yang berwujud penyimpangan-penyimpangan terhadap maksim dalam prinsip kerjasama dan prinsip kesopanan dalam humor-humor Gus Dur. Reliabilitas data diperoleh melalui car abaca dan kaji ulang (intra-rater).

Analisis data dilakukan dengan teknik deskriptif dengan langkah-langkah komparatif, kategorisasi, dan inferensi. Data yang terkumpul kemudian dipilah dan dikategorisasikan berdasarkan penyimpangan maksim-maksim yang ada. Langkah selanjutnya adalah menganalsis dan menarik inferensi serta simpulan tentang jenis dan wujud penyimpangan-penyimpangan terhadap maksim dalam prinsip kerjasama dan prinsip kesopanan yang digunakan sebagai sarana untuk memunculkan efek kelucuan dalam humor-humor Gus Dur.
HASIL DAN PEMBAHASAN

Penyimpangan Maksim Kerjasama (cooperative principles)

Wacana humor dikreasikan dan dibentuk dari penyimpangan prinsip kerjasama sehingga secara sengaja atau tidak sengaja perserta percakapan terlibat dalam proses komunikasi yang tidak wajar (non-bonafide communication). Dalam wacana nonhumor penutur selalu memperhatikan maksim-maksim percakapannya. Hal ini sangat berbeda dengan wacana humor. Jenis wacana ini berusaha agar tuturan yang dihasilkan melanggar maksim-maksim percakapan tersebut (Wijana, 2003).

Prinsip kerjasama yang disimpangkan tersebut meliputi empat maksim, yaitu maksim kuantitas, maksim kualitas, maksim relevansi, dan maksim pelaksanaan. Berikut ini akan dipaparkan temuan tentang penyimpangan prinsip kerjasama dari keempat maksim tersebut.

\section{Penyimpangan Maksim Kuantitas}

Lazimnya dalam melakukan proses komunikasi yang memenuhi prinsip kerjasama penutur seharusnya memberikan informasi sebanyak yang dibutuhkan lawan tutur. Namun, di dalam wacana humor Gus Dur prinsip dan ketentuan ini dilanggar atau disimpangkan. Penyimpangan maksim kuantitas ternyata mampu membentuk efek kelucuan, bahkan kadangkala mampu menimbulkan keterkejutan. Berdasarkan data yang terkumpul Gus Dur memanfaatkan penyimpangan maksim ini untuk menciptakan humor yang lucu. Hal ini terlihat dalam penggalan wacana berikut ini.

\section{Kaum Almarhum}

Mungkinkah Gus Dur benarbenar percaya pada isyarat dari makam-makam leluhur? Kelihatannya dia memang percaya, sebab 
Gus Dur selalu siap dengan gigih dan sungguh-sungguh membela "ideologi"nya itu. Padahal hal tersebut sering membuat repot para koleganya. Tapi, ini mungkin jawaban yang benar, ketika ditanya kenapa Gus Dur sering berziarah ke makam para ulama dan leluhur.

"Saya datang ke makam, karena saya tahu. Mereka yang mati itu sudah tidak punya kepentingan lagi." Katanya.

Dari penggalan wacana di atas dapat diketahui bahwa Gus Dur memberikan kontribusi yang berlebihan dan tidak sesuai dengan yang dibutuhkan dari pertanyaan. Hal ini dapat terlihat dari satuan lingual yang berbentuk, "Saya datang ke makam, karena saya tahu. Mereka yang mati itu sudah tidak punya kepentingan lagi." Semua orang sebenarnya tahu bahwa penghuni kuburan tidak lagi dapat berbuat apa-apa karena memang mereka telah mati, termasuk mereka tidak lagi memiliki kepentingan. Kontribusi yang diberikan Gus Dur jelas tidak memenuhi kebutuhan informasi lawan tutur. Namun, dengan cara menyimpangkan maksim kuantitas ternyata mampu memberikan dua hal sekaligus, yaitu efek kelucuan dan kritik sosial tidak langsung terhadap kondisi bangsa yang dipenuhi oleh banyak kepentingan pragmatis.

Berikut ini data penggalan wacana lain yang menunjukkan bahwa dalam menciptakan humor-humornya, Gus Dur berusaha memanfaatkan kreasi bahasa dengan jalan menyimpangkannya dari maksim kuantitas.

\section{Becak Dilarang Masuk}

Ceritanya ada seorang tukang becak asal Madura yang pernah dipergoki oleh polisi ketika melanggar rambu "becak dilarang masuk". Tukang becak itu masuk ke jalan yang ada rambu gambar becak disilang dengan garis hitam, yang berarti jalan itu tidak boleh dimasuki becak.

"Apa kamu tidak melihat gambar itu? Itu kan gambar becak tak boleh masuk jalan ini," bentak pak polisi. "Oh saya melihat pak, tapi itu kan gambarnya becak kosong, tidak ada pengemudinya. Becak saya kan ada yang mengemudi, tidak kosong berarti boleh masuk," jawab si tukang becak .

"Bodoh, apa kamu tidak bisa baca? Di bawah gambar itu kan ada tulisan bahwa becak dilarang masuk," bentak pak polisi lagi.

"Tidak pak, saya tidak bisa baca, kalau saya bisa membaca maka saya jadi polisi seperti sampeyan, bukan jadi tukang becak seperti ini," jawab si tukang becak sambil cengengesan.

Penggalan wacana di atas juga menunjukkan bahwa terjadi penyimpangan maksim kuantitas. Kontribusi yang diberikan 'tukang becak' terlihat berlebihan. Hal ini ditemukan dalam satuan lingual "Oh saya melihat pak, tapi itu kan gambarnya becak kosong, tidak ada pengemudinya. Becak saya kan ada yang mengemudi, tidak kosong berarti boleh masuk." Pertanyaan yang dilontarkan polisi sebenarnya merupakan bagian dari komunikasi fatik (phatic communication) yang mengimplikasikan kemarahan. Kontribusi 'tukang becak' seharusnya cukup sampai satuan lingual "Oh saya melihat pak" sehingga tidak terlihat berlebih-lebihan.

Fenomena ini diperkuat dengan pemanfaatan satuan lingual di akhir penggalan wacana "Tidak pak, saya tidak bisa baca, kalau saya bisa membaca maka saya jadi polisi seperti sampeyan, bukan jadi tukang becak seperti ini." Kontribusi yang diberikan 'tukang becak' sangat berlebihan dan tidak memenuhi kebutuhan in- 
formasi penutur. Hanya saja ternyata pemanfaatan penyimpangan maksim kuantitas dalam penggalan humor di atas mampu menciptakan efek kelucuan sekaligus kekonyolan.

\section{Penyimpangan Maksim Kualitas}

Dalam proses komunikasi masing-masing peserta percakapan harus secara kooperatif mengatakan sesuatu yang sebenarnya. Mereka seharusnya mengatakan sesuatu berdasarkan bukti-bukti yang memadai (Wijana, 2003: 82). Namun, untuk menciptakan efek kelucuan prinsip ini seringkali tidak dipatuhi, terutama dalam wacana humor. Demikian pula dengan humor-humor Gus Dur. Penyimpangan maksim kualitas dieksplorasi secara maksimal sehingga menciptakan efek kekonyolan dan kelucuan yang merangsang orang untuk tertawa. Sebagai contoh dapat diperhatikan penggalan wacana humor Gus Dur berikut ini.

\section{Cerita Gus Dur Soal Naik Kereta}

Setelah mendapat larangan dari dokternya untuk tidak melakukan perjalanan jauh dengan menggunakan pesawat terbang, Gus Dur kemudian nekat untuk berpergian jauh menggunakan kereta api.

"Anda mau pergi naik kereta api Gus? Memangnya Anda pikir bisa sampai tepat waktu dengan naik kereta api?" ledek si dokter.

"Anda jangan meremehkan, kereta itu cepet banget loh!" jawab mantan Presiden RI ke-4 itu.

"Kereta api mana yang bisa menandingi kecepatan pesawat terbang?" tanya dokter.

"Oho.. Anda jangan salah. Semua kereta api bisa lebih cepat dari pesawat," kilah pria kelahiran Jombang, Jawa Timur, 7 September 1940 ini.
"Anda mimpi kali. Semua orang juga tahu kalau pesawat itu jelas lebih cepat dibandingkan kereta api," cecar sang dokter.

"Wah, Anda salah. Memang sekarang ini pesawat lebih cepat. Tapi itu karena kereta api baru bisa merangkak. Coba kalau kereta api nanti sudah bisa berdiri dan bisa lari. Wuiih.. pasti bakalan jauh lebih cepat dari pesawat," jawab Gus Dur, disambut wajah kecut sang dokter. (rhs)

Efek kelucuan dalam penggalan wacana di atas dimunculkan dengan mengeksplorasi penyimpangan maksim kualitas. Kontribusi yang diberikan Gus Dur dari penggalan wacana di atas tidak logis karena tidak mungkin kereta api dapat berdiri dan berlari. Kebenaran pernyataan Gus Dur dalam humor di atas tidak dapat dibuktikan. Dengan cara menyimpangkan maksim kualitas dalam satuan lingual "Tapi itu karena kereta api baru bisa merangkak. Coba kalau kereta api nanti sudah bisa berdiri dan bisa lari. Wuiih.. pasti bakalan jauh lebih cepat dari pesawat," efek kelucuan dan kekonyolan berpikir terlihat sangat jelas sehingga dapat memunculkan kelucuan bagi pendengar atau pembaca. Seandaninya penyimpangan tersebut tidak dilakukan, efek kelucuan tidak dapat muncul dalam wacana sehingga tidak dapat merangsang orang untuk tertawa.

Efek kelucuan dengan memanfaatkan penyimpangan maksim kualitas juga terjadi dalam wacana humor berikut ini.

\section{Soeharto Pilih NU 'Diskon'}

Suatu hari, di bulan Ramadan, Gus Dur bersama seorang kiai lain (kiai Asrowi) pernah diundang ke kediaman mantan presiden Soeharto untuk buka bersama. Setelah buka, 
kemudian salat Maghrib berjamaah. Setelah minum kopi, teh dan makan, terjadilah dialog antara Soeharto dan Gus Dur.

Soeharto:“Gus Dur sampai malam di sini?"

Gus Dur:"Engga Pak! Saya harus segera pergi ke "tempat lain'."

Soeharto:"Oh iya ya ya... silaken. Tapi kiainya kan ditinggal di sini ya?"

Gus Dur: “Oh, iya Pak! Tapi harus ada penjelasan."

Soeharto:"Penjelasan apa?"

Gus Dur: "Salat Tarawihnya nanti itu 'ngikutin' NU lama atau NU baru?" Soeharto jadi bingung, baru kali ini dia mendengar ada NU lama dan NU baru. Kemudian dia bertanya.

Soeharto:"Lho NU lama dan NU baru apa bedanya?"

Gus Dur: "Kalau NU lama, Tarawih dan Witirnya itu 23 rakaat."

Soeharto:"Oh iya iya ya ya... ga apaapa...." Gus Dur sementara diam.

Soeharto: "Lha kalau NU baru?"

Gus Dur: "Diskon 60\% !" Hahahahahaha.... (Gus Dur, Soeharto, dan orang-orang yang mendengar dialog tersebut pun tertawa.)

Gus Dur: "Ya, jadi salat tarawih dan witirnya cuma tinggal 11 rakaat."

Soeharto:"Ya sudah, saya ikut NU baru aja, pinggang saya sakit."

Wacana di atas melanggar maksim kualitas karena dianggap tidak logis. Tidak ada bukti yang memperkuat tentang keberadaan NU lama dan NU baru dalam konteks kemasyarakatan, apalagi jika standarnya adalah jumlah rakaat dalam shalat tarawih. Perbedaan tersebut, biasanya terjadi antara ormas NU dengan Muhammadiyah, bukan antara NU lama dan NU baru. Penyimpangan berikutnya dilakukan dengan menyatakan bahwa NU baru memberikan diskon $60 \%$ dari shalat tarawih NU lama yang berjumlah 23 rakaat. Satuan lingual yang menunjukkan hal tersebut adalah sebagai berikut.
Soeharto: "Lho NU lama dan NU baru apa bedanya?"
Gus Dur:" Kalau NU lama, Tarawih dan Witirnya itu 23 rakaat."
Soeharto: "Oh iya iya ya ya... ga apa- apa...."

Gus Dur sementara diam.

Soeharto: "Lha kalau NU baru?"

Gus Dur:"Diskon 60\% !”

Penggalan wacana inilah yang menimbulkan efek kelucuan. Sementara satuan lingual lainnya menjadi konteks yang mendukung orang untuk memahami satuan lingual di atas. Pemahaman terhadap konteks tersebut yang akan memperkuat persepsi para penikmat humor-humor Gus Dur memiliki efek kelucuan yang baik. Satuan-satuan lingual di atas didukung oleh satuan lingual berikutnya yang berupa kontribusi dari Soeharto, yaitu "Ya sudah, saya ikut NU baru aja, pinggang saya sakit."

\section{Penyimpangan Maksim Relevansi}

Dalam proses komunikasi penutur dan lawan tutur dituntut untuk selalu relevan mengemukakan maksud dan ide-idenya. Maksim relevansi menekankan keterkaitan antara isi ujaran dengan konteksnya agar proses berbahasa dapat berlangsung secara efektif. Dalam proses komunikasi hal ini harus diperhatikan. Akan tetapi, wa- 
cana humor berusaha sebaliknya. Upaya untuk menimbulkan efek kelucuan diekspresikan melalui penyimpangan maksim relevansi. Hal yang sama terjadi dalam wacana humor-humor Gus Dur. Tokoh-tokoh diciptakan sedemikian rupa untuk salah menafsirkan konteks pembicaraan atau dibuat secara sengaja memahami konteks pembicaraan secara salah dari maksud lawan bicaranya.

Humor bertajuk 'Cuma Takut Tiga Roda' berikut ini memberikan deskripsi yang lebih jelas tentang kecenderungan pemakaian maksim relevansi secara menyimpang.

\section{Cuma Takut Tiga Roda}

Suatu hari, saat Abdurarahman Wahid menjabat sebagai Presiden RI, ada pembicaraan serius. Pembicaraan bertopik isu terhangat dilakukan selesai menghadiri sebuah rapat di Istana Negara. Diketahui, pembicaraan itu mengenai wabah demam berdarah yang kala itu melanda kota Jakarta. Gus Dur pun sibuk memperbincangkan penyakit mematikan tersebut.

"Menurut Anda, mengapa demam berdarah saat ini semakin marak di Jakarta Pak?" tanya seorang menterinya.

"Ya karena Gubernur DKI Jakarta Sutiyoso melarang bemo, becak, dan sebentar lagi bajaj dilarang beredar di Kota Jakarta ini. Padahal kan nyamuk sini cuma takut sama tiga roda...!" (rhs)

Penggalan wacana humor Gus Dur di atas membuktikan tentang pemanfaatan penyimpangan maksim relevansi untuk menciptakan efek kelucuan. Terlihat sangat jelas bahwa kontribusi Gus Dur memiliki tipe yang berbeda dari satuan lingual sebelumnya yang cenderung serius karena sedang membahas permasalahan wabah demam berdarah di Jakarta. Satuan lingual yang merupakan kontribusi Gus Dur menunjukkan bahwa Gus Dur secara sengaja menafsirkan maksud kontribusi menteri secara salah dengan menyatakan "Ya karena Gubernur DKI Jakarta Sutiyoso melarang bemo, becak, dan sebentar lagi bajaj dilarang beredar di Kota Jakarta ini. Padahal kan nyamuk sini cuma takut sama tiga roda...!"

Kontribusi yang diberikan Gus Dur tidak berhubungan secara langsung dengan konteks pembicaraan, tetapi dikaitkan dengan konteks yang lain. Konteks yang dimaksud adalah iklan salah satu produk obat nyamuk. Tentu saja satuan lingual yang merupakan penyimpangan dari maksim relevansi di atas mampu menciptakan efek kelucuan, terlebih ketika pelibat komunikasi mampu memahami konteks wacana iklan obat nyamuk tersebut.

Penyimpangan maksim relevansi ternyata dimanfaatkan juga untuk menciptakan wacana humor yang tidak hanya menimbulkan efek kelucuan tetapi juga menyampaikan kritik sosial. Penggalan wacana humor berikut ini mendeskripsikan tentang hal tersebut.

\section{Tiga Polisi Jujur}

Gus Dur sering terang-terangan ketika mengkritik. Tidak terkecuali ketika mengkritik dan menyindir polisi. Menurut Gus Dur di negeri ini hanya ada tiga polisi yang jujur. "Pertama, polisi Hoegeng (mantan Kapolri). Kedua, patung polisi. Ketiga, polisi tidur." Kata Gus Dur sambil tersenyum.

Berdasarkan penggalan wacana humor di atas dapat diketahui bahwa yang menimbulkan kelucuan adalah tuturan Gus Dur yang berupa: "Pertama, polisi Hoegeng (mantan Kapolri). Kedua, patung polisi. Ketiga, polisi tidur." Tuturan tersebut merupakan kontribusi yang melanggar maksim relevansi. Memang 
di antara ketiga hal di atas (Hoegeng, patung polisi, dan polisi tidur) memiliki keterkaitan dengan polisi. Hanya saja berdasarkan konteks wacana tentang kejujuran polisi, pemahaman yang memungkinkan adalah manusia yang memiliki sifat-sifat jujur dan mereka harus berprofesi sebagai polisi. Namun, tuturan Gus Dur merupakan kontribusi yang melanggar maksim relevansi. Untuk menimbulkan kekonyolan, kelucuan, dan sekaligus kritik tajam terhadap integritas polisi Gus Dur mengaitkan tuturannya dengan patung polisi dan polisi tidur.

Penyebutan Hoegeng di awal dapat diterima secara logis. Artinya, penyebutan nama Hoegeng sebagai salah satu perwira polisi yang memiliki integritas kejujuran dapat diterima banyak orang. Akan tetapi, penyertaan $p a-$ tung polisi dan polisi tidur dalam tuturan tersebut menimbulkan efek kekonyolan sekaligus kritik sosial yang tajam terhadap institusi polisi. Langkah yang dilakukan adalah dengan mengreasikan bahasa melalui penyimpangan maksim relevansi.

\section{Penyimpangan Maksim Pelaksanaan}

Maksim pelaksanaan mengharapkan setiap peserta komunikasi untuk menyampaikan maksudnya secara jelas. Untuk memperoleh kejelasan tersebut, peserta tutur seharusnya berbicara dengan menghindari kekaburan (obscurity), ketaksaan (ambiguity), berbicara secara padat (concise), runtut, serta langsung (straightforward) (Wijana, 2003: 89). Dalam humor ketaksaan sering dimanfaatkan untuk menciptakan keterkejutan sekaligus kekonyolan yang dapat menyebabkan seseorang tertawa.

Beberapa humor Gus Dur menjadikan ketaksaan sebagai kekuatan untuk menimbulkan efek kelucuan. Biasanya ketaksaan terlihat dalam penafsiran dan pemahaman tokoh rekaan Gus Dur yang berbeda terhadap satu wacana atau satuan lingual tertentu. Data berikut memberikan deskripsi yang lebih jelas dari penjelasan ini.

\section{Peluru pun Habis}

Ini cerita Gus Dur tentang situasi Rusia, tidak lama setelah bubarnya Uni Soviet. sosialisme hancur, dan para birokrat tidak punya pengalaman mengelola sistem ekonomi pasar bebas. Pada masa sosialisme, memang rakyat sering antre untuk mendapatkan macam-macam kebutuhan pokok, tapi manajemennya rapi, sehingga semua orang kebagian jatah. Sekarang, masyarakat tetap harus antre, tapi karena manejemennya jelek, antrean umumnya sangat panjang, dan banyak orang yang tidak kebagian jatah.

Begitulah, seorang aktivis sosial berkeliling kota Moskow untuk mengamati bagaimana sistem baru itu bekerja. di sebuah antrean roti, setelah melihat banyaknya orang yang tidak kebagian, aktivis itu menulis di buku catatannya, "roti habis."

Lalu dia pergi ke antrean bahan bakar. lebih banyak lagi yang tak kebagian. Dia mencatat "bahan bakar habis!", kemudian dia menuju ke antrean sabun. Wah pemerintah kapitalis baru ini betul-betul brengsek, banyak sekali masyarakat yang tidak mendapat jatah sabun. Dia menulis besar-besar "sabun habis!"

Tanpa dia sadari, dia diikuti oleh seorang intel KGB. Ketika akan meninggalkan antrean sabun itu, si intel menegur, "Hei bung! Dari tadi kamu sibuk mencatat-catat terus, apa sih yang kamu catat?" Sang aktivis menceritakan bahwa dia sedang melakukan penelitian tentang kemampuan pemerintah dalam mendistribusikan barang bagi rak- 
yat. "Untung kamu ya, sekarang sudah zaman reformasi", ujar sang intel, "Kalau dulu, kamu sudah ditembak".

Sambil melangkah pergi, aktivis itu mencatat, "peluru juga habis!"

Sang aktivis mengalami ketaksaan untuk memahami kontribusi intel KGB, yaitu Untung kamu ya, sekarang sudah zaman reformasi", dan "Kalau dulu, kamu sudah ditembak". Makna dari kontribusi ini sebenarnya menyatakan bahwa sang intel tidak akan mempermasalahkan kegiatan penelitian aktivis sosial, apalagi menembaknya, seperti yang dilakukan pada masa otoriter karena sekarang sudah masa reformasi. Namun, dua satuan lingual tersebut dipahami secara berbeda oleh aktivis sosial dengan satuan lingual lain, yaitu "peluru juga habis!" Penyimpangan maksim pelaksanaan ini dapat menciptakan efek kelucuan.

Bentuk-bentuk ketaksaan lain yang dieksplorasi untuk mendukung wacana humor dapat ditemukan dalam penggalan berikut ini.

\section{Radio Islami}

Seorang Indonesia yang baru pulang menunaikan ibadah haji terlihat marah-marah.

"Lho kang, ngopo (kenapa) ngamuk-ngamuk mbanting radio?" tanya kawannya penasaran.

“Pembohong! Gombal!" ujarnya geram. Temannya terpaku kebingungan. "Radio ini di Mekkah tiap hari ngaji Al-Qur'an terus. Tapi di sini, isinya lagu dangdut tok. Radio begini kok dibilang radio Islami."

"Sampean tahu ini radio Islami dari mana?"

"Lha..., itu bacaannya 'alltransistor', pakai ' $\mathrm{Al}^{\prime}$."
Penggalan di atas jelas berusaha mengaburkan pemahaman tentang radio, yang tergantung pada stasiun penyiarannya dengan makna radio Islami. Pengaburan pemahaman sekaligus ketaksaan definisi 'radio Islami' dimanfaatkan untuk menciptakan efek kekonyolan jamaah haji dari Indonesia. Kekonyolan yang terbentuk mampu memunculkan kelucuan bagi pembaca.

\section{Penyimpangan Maksim Kesopanan}

Proses komunikasi tidak hanya menuntut dipatuhinya prinsip kerjasama, tetapi juga prinsip kesopanan. Maksim kesopanan secara umum mengatur cara-cara peserta komunikasi berinteraksi dalam upaya menghargai dan menghormati lawan bicaranya (Wijana, 2003: 96). Kepatuhan terhadap prinsip kerjasama dan kesopanan tidak selalu terjadi dalam wacana humor. Seringkali kedua prinsip tersebut dilanggar dengan menyimpangkan maksim-maksimnya, termasuk di dalamnya maksim-maksim dalam prinsip kesopanan.

Humor-humor Gus Dur juga memanfaatkan penyimpangan ini. Ada tiga maksim yang disimpangkan dalam humor Gus Dur, yaitu maksim kemurahan, maksim kebijaksanaan, dan maksim kerendahan hati. Berikut ini akan dibahas masing-masing penyimpangan maksim tersebut.

\section{Penyimpangan Maksim Kemurahan}

Maksim kemurahan berpusat pada diri sendiri. Maksim ini menggariskan setiap peserta komunikasi untuk memaksimalkan kerugian dan meminimalkan keuntungan diri sendiri. Dalam wacana humor Gus Dur penyimpangan ini dilakukan dengan menciptakan tokoh-tokoh (termasuk Gus Dur sendiri) yang berusaha memaksimalkan keuntungan dan meminimalkan kerugian diri pribadinya, termasuk keuntungan dari sisi pencitraan. Untuk itu dapat di- 
simak implikasi wacana humor Gus Dur berikut ini.

\section{Fenomena 'Gila' Gus Dur}

Melekatnya predikat humoris pada Presiden RI yang keempat itu pun sempat membuat Presiden Kuba Fidel Alejandro Castro Ruz penasaran. Suatu ketika, keduanya berkesempatan bertemu. Seperti yang diceritakan oleh mantan Kepala Protokol Istana Presiden Wahyu Muryadi pada tayangan televisi, Fidel Castro bertanya kepada Gus Dur mengenai joke teranyarnya.

Dijawablah oleh Gus Dur, "Di Indonesia itu terkenal dengan fenomena 'gila,'" Fidel Castro pun menyimak pernyataan mengagetkan tersebut. "Presiden pertama dikenal dengan gila wanita. Presiden kedua dikenal dengan gila harta. Lalu, presiden ketiga dikenal gila teknologi," tutur Gus Dur yang kemudian terdiam sejenak. Fidel Castro pun semakin serius mendengarkan lanjutan cerita.

"Kemudian, kalau presiden keempat, ya yang milih itu yang gila," celetuk Gus Dur. Fidel Castro pun diceritakan terpingkal-pingkal mendengar dagelan tersebut. (rhs)

Efek kelucuan muncul dalam satuan lingual berupa "Kemudian, kalau presiden keempat, ya yang milih itu yang gila." Satuan lingual 'presiden keempat' jelas menyaran pada Gus Dur atau $\mathrm{KH}$ Abdurrahman Wahid sebagai presiden Indonesia keempat. Jika presiden-presiden lain dilekatkan identitas kegemaran (kegilaan) terhadap wanita (presiden pertama), harta (presiden kedua), dan teknologi (presiden ketiga), untuk Gus Dur (presiden keempat) tidak dilekatkan pada kegemaran. Satuan lingual 'gila' diarahkan pada pemilihnya, yaitu anggota Majelis Permusyawaratan
Rakyat (MPR) RI. Dalam konteks ini terlihat bahwa Gus Dur menyimpangkan maksim kemurahan dengan menyudutkan ketiga presiden RI sebelumnya dan anggota MPR sebagai pemilih gila. Sementara dirinya sendiri dalam posisi lebih terhormat dan tidak dirugikan. Cara ini menimbulkan efek kelucuan dalam wacana humor di atas.

\section{Penyimpangan Maksim Kebijaksanaan}

Maksim kebijaksanaan mengharapkan setiap peserta tindak tutur meminimalkan kerugian orang lain atau memaksimalkan keuntungan orang lain. Dalam wacana humor Gus Dur terdapat beberapa wacana yang mengindikasikan dimanfaatkannya penyimpangan maksim kebijaksanaan melalui kecenderungan untuk merendahkan orang lain. Dalam hal ini, fokus maksim kebijaksanaan terletak pada orang lain.

\section{Pengalaman Gus Dur Naik Haji}

Suatu kali Presiden Soeharto berangkat ke Mekkah untuk berhaji. Karena yang pergi seorang persiden, tentu sejumlah menteri harus ikut mendampingi. Salah satunya "peminta pertunjuk" yang paling rajin, Menteri Penerangan Harmoko.

Setelah melewati beberapa ritual haji, rombongan Soeharto pun melaksanakan jumrah, yakni simbol untuk mengusir setan dengan cara melempar batu ke sebuah tiang mirip patung. Di sini lah muncul masalah, terutama bagi Harmoko.

Beberapa kali batu yang dilemparkannya selalu berbalik menghantam jidatnya. "Wah kenapa jadi begini ya?" cerita Gus Dus menuturkan pernyataan Harmoko yang saat itu tampak gemetar karena takut.

Lalu Harmoko pindah posisi. Hasilnya sama saja, batu yang dilemparnya seperti ada yang melempar balik ke arah dirinya. Setelah tujuh 
kali lemparan hasilnya selalu sama, Harmoko pun menoleh ke kanan dan ke kiri, mencari-cari posisi presiden untuk "minta petunjuk". Setelah ketemu, lalu dengan lega ia tergopoh-gopoh menghampiri Bapak Presiden. Namun, sebelum sampai di hadapan Soeharto, ia turut mendengar bisikan "Hai manusia, sesama setan jangan saling lempar." (rhs)

Efek kelucuan terdapat dalam satuan lingual "Hai manusia, sesama setan jangan saling lempar." Kontribusi dari suara ghaib tersebut didukung oleh konteks-konteks satuan lingual sebelumnya yang mampu menggiring pada aspek keterkejutan. Penyimpangan maksim kebijaksanaan dilakukan dengan memaksimalkan kerugian orang lain serta meminimalkan keuntungan orang lain. Kerugian bagi orang lain itu dapat berupa kerugian dalam aspek pencitraan. Dalam konteks wacana humor di atas, Harmoko dicitrakan sebagai setan atau manusia yang memiliki karakter setan.

\section{Penyimpangan Maksim Kerendahan hati}

Maksim kerendahan hati menuntut setiap penutur untuk semaksimal mungkin tidak hormat pada dirinya sendiri atau seminimal mungkin memberikan hormat bagi dirinya sendiri. Jenis maksim ini disimpangkan dalam wacana humor Gus Dur. Namun kadangkala sebuah kontribusi menyimpang dari maksim ini dengan tujuan untuk memunculkan rasa humor. Berikut ini penggalan wacana humor Gus Dur yang membuktikan penyimpangan maksim kerendahan hati.

\section{Lagi Asyik Baca}

Bertahun-tahun, saya heran kenapa sih Indonesia "Tidak majumaju" meski mereka sudah merdeka 60 tahun lebih. Tapi sekarang...saya sudah tahu alasannya. Berdasarkan data statistik: Jumlah penduduk Indonesia ada 225 juta. 100 juta di antaranya adalah para pensiunan dan anak-anak. Jadi yang kerja cuma 125 juta.

Jumlah pelajar dan mahasiswa adalah 78 juta. Jadi tinggal 47 orang yang kerja. Yang kerja buat pemerintah pusat jadi pegawai negeri ada 31 juta, jadi tinggal 16 juta yang kerja (karena PNS cuma main catur dan baca koran). Ada 4,5 juta yang jadi TNI dan Polisi. Jadi tinggal 11,5 juta yang kerja (karena TNI dan Polisi tidak ada kerjaan).

Ada lagi yang kerja di pemerintahan daerah dan departemen-departemen lain jumlahnya 10.500.000. Jadi sisanya tinggal 1.000.000. Yang sakit dan dirawat di Rumah Sakit di seluruh Indonesia ada 888.000. Jadi sisa 112.000 orang saja yang kerja. Ada 111.998 orang yang di penjara. Jadi tinggal sisa dua orang saja yang masih bisa kerja. Siapa mereka? Yaaa...tentu saja SAYA dan ANDA! Tapi kan sekarang ANDA lagi asyik baca tulisan ini sambil cekikakcekikik sendiri. Jadi tinggal saya sendiri dong yang kerja! Pantes aja kalau begini Indonesia tidak majumaju........!

Unsur penyebab kelucuan penggalan wacana di atas terletak pada penyudutan pembaca dan pengunggulan diri Gus Dur sebagai penutur. Unsur tersebut berupa satuan lingual yang berupa "Jadi tinggal sisa dua orang saja yang masih bisa kerja. Siapa mereka?Yaa... tentu saja SAYA dan ANDA! Tapi kan sekarang ANDA lagi asyik baca tulisan ini sambil cekikak-cekikik sendiri. Jadi tinggal saya sendiri dong yang kerja! Pantes aja kalau begini Indonesia tidak maju-maju...!" Satuan lingual tersebut merupakan bagian dari kontribusi yang diberikan oleh Gus 
Dur. Kontribusi tersebut menyimpang dari maksim karena dengan kontribusi tersebut Gus Dur mengarahkan untuk menghormati diri sendiri, sekaligus memojokkan orang lain.

\section{SIMPULAN}

Efek kelucuan dalam humorhumor Gus Dur dimunculkan melalui pemanfaatan kreasi bahasa tertentu. Wacana humor-humor Gus Dur tersebut terjadi karena penyimpangan implikatur percakapan (conversational implicature). Hal ini dilakukan dengan menyimpangkan prinsip pertuturan yang seharusnya dipatuhi dalam proses komunikasi. Dalam wacana humor Gus Dur, penyimpangan prinsip kerjasama dan kesopanan dilakukan untuk menciptakan efek kelucuan.

Maksim-maksim yang disimpangkan dalam humor-humor Gus Dur dalam prinsip kerjasama dapat dijelaskan sebagai berikut. Maksim kuantitas dilakukan dengan memberikan kontribusi yang berlebihan. Maksim kualitas disimpangkan dengan pemberian kontribusi yang tidak logis serta tidak didukung dengan pembuktian. Maksim relevansi dilakukan dengan memberikan kontribusi yang tidak relevan dengan masalah pembicaraan, sedangkan maksim dilaksanakan dengan pemberian kontribusi yang taksa.

Sementara itu, penyimpangan terhadap maksim-maksim dalam prinsip kesopanan dapat dipaparkan sebagai berikut. Penyimpangan maksim kebijaksanaan dilakukan melalui kecenderungan untuk memberikan kontribusi yang merendahkan orang lain. Penyimpangan maksim kemurahan dilakukan dengan menciptakan kontribusi tokohtokoh (termasuk Gus Dur sendiri) yang berusaha memaksimalkan keuntungan dan meminimalkan kerugian diri pribadinya, termasuk keuntungan dari sisi pencitraan. Penyimpangan maksim ke- rendahhatiaan dilakukan dengan pemberian kontribusi yang diarahkan untuk menghormati diri sendiri, sekaligus memojokkan orang lain.

\section{UCAPAN TRIMA KASIH}

Artikel ini diangkat dari penelitian mandiri swadana yang dilaksanakan pada tahun 2009. Ucapan terima kasih disampaikan kepada mitra sejawat yang telah membantu kegiatan verifikasi dan triangulasi data dan hasil penelitian. Ucapan terima kasih juga disampaikan kepada Dr. Suhardi, M.Pd. selaku pengampu mata kuliah Analisis Wacana di Pascasarjana UNY yang telah memberi arahan, bimbingan aspek-aspek teroritik dalam kaitannya dengan kajian wacana.

\section{DAFTAR PUSTAKA}

Danandjaja, James. 1999. Humor Asli Mahasiswa. Jakarta: Pustaka Sinar Harapan

Doyin, Mukh. 2006. "Corak Anekdot Indonesia". Dalam Litera volume 5, Nomor 1, Januari. Halaman 7794.

Grice, H. Paul. 1975. Logic and Conversation. New York. Academic Press.

Leech, Geoffrey. 1983. Principles of Pragmatic. New York: Longman

Mulyana. 2005. Kajian Wacana: Teori, Metode $\mathcal{E}$ Aplikasi Prinsip-prinsip Analisis Wacana. Yogyakarta: Tiara Wacana

Mulyani, Siti. 2006. "Wacana pada Produk Dagadu Djogdja, Upaya Pemahaman Metapesan". Dalam Litera volume 5, Nomor 1, Januari. Halaman 65-76.

Mulyani, Siti. 2002. Penyimpangan Aspek Pragmatik dalam Wacana Humor Verbal Tulis Berbahasa Jawa. Dalam Litera Tahun I, Nomor 1, Januari. Halaman 39-49

Wijana, I Dewa Putu. 2003. Kartun. Yogyakarta: Ombak 